УДК 343.9

DOI https://doi.org/10.32837/pyuv.v1i4(29).413

\author{
B. B. Tonчiŭ \\ orcid.org/0000-0001-8979-1483 \\ кандидат юридичних наук, прокурор \\ Прокуратури Київської області
}

\title{
ГЕОГРАФІЯ ЗЛОЧИННОСТІ У СФЕРІ ІНТЕЛЕКТУАЛЬНОЇ ВЛАСНОСТІ В УКРАЇНІ
}

Аналіз географії злочинності є необхідністю для з'ясування специфіки причин та умов злочинності в різних географічних районах з погляду впливу на них місцевих особливостей та врахування їх при розробленні заходів запобігання злочинності у сфері інтелектуальної власності. Географія злочинності має велике практичне значення для диференційованої оцінки результатів роботи правоохоронних органів, їх служб та підрозділів, визначення ними гарячих точок, маневрування силами та засобами, планування всього процесу боротьби зі злочинністю. При вивченні географії злочинності на рівні суб'єктів держави досліджуються її кримінологічні характеристики відносно міст та районів; на рівні міста з районним поділомвідносно районів; на рівні району, міста, селища відносно населених пунктів, мікрорайонів, адміністративних ділянок, підприємств та інших об'єктів. Також мають значення і теоретичні дослідження, оскільки з'являється можливість глибше вивчити механізм детермінації злочинності та її змін, встановити закономірності появи та функціонування злочинності в різних за своїми соціально-економічними, соціально-культурними та іншими характеристиками регіонах, визначати в цих закономірностях загальне та специфічне. Все це є необхідною передумовою для вироблення стратегічних заходів запобігання злочинності у сфері інтелектуальної власності.

Дослідження особливостей злочинності у сфері інтелектуальної власності в регіонах та їх причин не звільняє від необхідності врахування специфіки злочинності на загальносоціальному та соціальногруповому рівнях. При цьому додатково враховується регіональний (територіальний) фактор.

Що ж саме дає нам вивчення географії злочинності? Яка ж мета, завдання та специфіка їі вивчення? Який має бути підхід до аналізу демографічних явищ та процесів?

Розв'язанню цих питань сприяє територіальний кримінологічний аналіз, який, по-перше, допомагає чітко окреслити зони з найбільш високою інтенсивністю злочинності, де необхідно зосередити увагу державних органів та громадськості і виявити особливу активність і послідовність у боротьбі з протиправними діями у сфері інтелектуальної власності. По-друге, такий аналіз дає можливість виділити зони з найменшою інтенсивністю злочинних проявів.
Вивчення та узагальнення позитивного досвіду боротьби зі злочинністю у сфері інтелектуальної власності на території району, міста, області грунтується на аналізі показників кримінальної статистики, що характеризують рівень злочинності як в абсолютних цифрах, так і в коефіцієнтах.

По-третє, географічний підхід дозволяє диференційовано зобразити загальний стан справ зі злочинністю, визначити регіональні тенденції в напрямі організації на державному рівні та активізації боротьби у сфері інтелектуальної власності в певний час та в певному місці. 3 метою виявлення зон росту злочинності, зон зниження ïi інтенсивності i, зрештою, зон, де простежується стабілізація рівня злочинних діянь, аналізуються показники динаміки злочинності у сфері інтелектуальної власності за певний період.

По-четверте, аналіз структури злочинності по регіонах дає можливість диференціювати кожний 3 них 3 погляду тяжкості та небезпечності основної кількості вчинених злочинів, а також поширення того чи іншого виду посягання.

По-п'яте, дослідження демографічних процесів (як і інших соціальних явищ) з урахуванням регіональних відмінностей злочинності допомагає виявити причини антисуспільної поведінки у сфері інтелектуальної власності та виробити систему профілактичних заходів боротьби з нею. До речі, порушення питань про вплив соціально-демографічних процесів на виникнення регіональних відмінностей ілюструє не лише певну частину загальної проблеми причин злочинності, а зазначену проблему в цілому. Це, зокрема, стає зрозумілим при співвідношенні понять «причини злочинності» та «причини відмінностей злочинності» [1].

Географічна поширеність злочинів проти інтелектуальної власності також має свої особливості, зумовлені тим, що ці кримінальні діяння переважно пов'язані із здійсненням наукової, господарської та підприємницької діяльності. 3 огляду на це особливо поширеними вони є у великих регіонах країни (Дніпропетровській, Київській, Одеській та Харківських областях), оскільки саме на цій території сконцентрований інтелектуальний, фінансовий і виробничий потенціал держави. Не випадково, що третина всіх злочинів проти інтелектуальної власності в Україні вчиняється в цих регіонах. Достатньо високими є показники виявлених злочинів цієї групи також в Львівській 
області та в місті Києві. Показовими у цьому відношенні є статистичні дані про злочини проти інтелектуальної власності у Київській області. Так, згідно з інформацією Головного управління статистики у Київській області, наведеною на підставі даних адміністративної звітності Міністерства внутрішніх справ України, прокуратури Київської області та м. Києва, територіального управління державної судової адміністрації України у Київській області, за період з 2013 по 2019 р. у цьому регіоні виявлено 2436 таких злочинів (19,64\% від загальної кількості злочинів проти інтелектуальної власності, зафіксованих за аналогічний період на території всієї України). Ця цифра становить 1,02\% від загальної кількості кримінальних правопорушень, зафіксованих на території області. Схожі статистичні показники злочинів цієї групи характерні також для Дніпропетровської, Одеської та Харківської областей. На регіональному рівні зберігаються і хвильові коливання показників злочинів проти інтелектуальної власності (від 51 до 91), характерні для аналогічних показників у загальнодержавному масштабі, а їхня середня кількість становить трохи більше 72 щорічно. Як і загалом в Україні, на регіональному рівні абсолютну перевагу мають злочини проти авторського права і суміжних прав (ст.ст. 176 та 203-1 КК України). Зокрема, за даними Головного управління статистики у Київській області, за останні п'ять років їх виявлено 314 (82,4\%). Злочинів проти інтелектуальної власності та результатів науково-технічної діяльності (ст.ст. 177, 231 та 232 (дві останні статті лише у частинах, які стосуються комерційного найменування)) зафіксовано 14 (3,7\% ), а злочинів проти інтелектуальної власності та результатів індивідуалізації товарів (послуг) і їх виробників (ст. 229 КК України) - 53 (13,9\%). При цьому збільшення частки злочинів проти інтелектуальної власності та результатів науково-технічної діяльності порівняно із відповідним показником у загальнодержавному масштабі (на 1,2\%) пояснюється зосередженням у цьому регіоні значного науково-технічного потенціалу.

Злочинність в містах та сільській місцевості має дуже багато відмінностей. Сільська злочинність має яскраво виражений маргінальний характер, що виявляється в низькому освітньому рівні злочинців (вищу і неповну вищу освіту мали лише 2,6\%), у високому ступені алкоголізації $(51,7 \%)$, у низькому ціновому порозі крадіжок (до 1 тис. грн (56,9\%)), у паразитичному способі життя і відсутності якої-небудь певної професії, постійного місця роботи $(52,5 \%)$. Сільські злочинці - це особи, які переважно ніде не працюють або перебиваються випадковими тимчасовими заробітками, не влаштовані в родинному житті $(57,8 \%)$. Злочини корисливої спрямованості вчинялися з метою здобути засоби на придбання спиртного, продуктів харчування тощо, що свідчить про примітивність інтересів і запитів, низьку культуру дозвілля, домінування при цьому вживання алкоголю.

Специфічною особливістю, що відрізняє сільського від міського злочинця, є те, що переважно це місцеві жителі $(94,97 \%)$, їх питома вага збільшується у міру віддаленості сільських поселень від адміністративних центрів. Вчинення злочинів найбільш властиве особам у віці 21-40 років (59,3\%), пік криміналізації відводиться на вікову групу 3040 років (26,2\% ). При цьому в групах осіб після сорокалітнього віку, де традиційно відбувається спад активності, в нашому дослідженні вони займають друге місце по мірі криміналізації (22,7\%). Частина жінок є незначною, але особливість полягає в тому, що основна криміногенна вікова категорія - жінки до 30 років (57\%). Серед жінок поширена алкоголізація (50\%), існує високий відсоток непрацюючих (85,7\% ) та тих, що не мають сім'ї (42,8\% ).

Специфічним для сільських злочинців є високий відсоток знайомств між злочинцем і потерпілим $(91,8 \%)$, що значно вище, ніж в інших злочинах. Високий серед них і відсоток осіб, що знаходяться в стані алкогольного сп'яніння $(54 \%)$. Високий рівень злочинів, вчинених у складі групи $(17,1 \%)$. Багато в чому це пов' язано з особливістю предметів, що викрадаються. Ці предмети характеризуються значною вагою і об'ємом, якісними особливостями, котрі зумовлюють необхідність виконання трудомістких операцій (насіння соняшнику, зернові культури, птиця, тварини і так далі). Злочини часто пов'язані з транспортуванням викраденого (35,9\%). При цьому із збільшенням складу групи до 3 -х і більше осіб в них, як правило, беруть участь родичі - брати, дружини, діти й інші близькі [2], що не притаманно злочинам у сфері інтелектуальної власності.

У містах рівень освіти та розвитку набагато вищий, тому й запити тут в злочинців вищі саме у сфері інтелектуальної власності. Однак зубожіння населення в цілому в деякій мірі спонукає до мізерних злочинів. Економічна нестабільність призводить до зрівняння внутрішніх чинників кримінологічних показників як в сільській, так і міській місцевості.

Міста сприяють зростанню злочинності у сфері інтелектуальної власності. На відміну від сіл та містечок, де швидко всі дізнаються про нову людину, великі міста переповнені незнайомцями. Безпека сусідів переважно залежить від поліції. Однак поліція не може стримувати злочинність самостійно. Важлива роль у справі стримування злочинності надається потенційним свідкам, котрі добре знають свої квартали та їх мешканців.

Географія злочинності - кількісно-якісний статистичний показник, який відображений 
в первинному обліку злочинів правоохоронними органами за місцем їх вчинення, що містить відомості про злочинця та потерпілого, дані про моральні та матеріальні втрати внаслідок вчинення злочинів, а також характеризує структуру злочину як співвідношення між групами та видами злочинів, вчинених різними категоріями правопорушників у окремо взятих адміністративнотериторіальних одиницях.

Вивчення географії злочинності дозволяє з'ясувати специфіку причин та умов злочинності в різних географічних районах з погляду впливу на них місцевих особливостей. Це дозволяє врахувати ці причини при розробленні системи профілактики. Багато вчених визначає поняття «географія злочинності» i «територіальні відмінності злочинності» як суміжні, але не ідентичні. Вони Iрунтуються на вивченні регіональних особливостей злочинності, але під географією злочинності розуміється порівняльний аналіз її особливостей в конкретних адміністративно-територіальних утвореннях, тоді як територіальні відмінності злочинності як ширше поняття охоплює всі можливі підстави (фактори), які впливають на такі відмінності. Вивчення географії злочинності (тобто порівняння злочинності в конкретних областях та населених пунктах) є лише частиною аналізу територіальних відмінностей злочинності [3].

За основу аналізу територіальних відмінностей злочинності у сфері інтелектуальної власності беруться загальні соціально-економічні, демографічні, соціально-культурні, географічні, історичні тощо властивості, а також стан правовиховної та правоохоронної діяльності, де здійснюється реалізація однієї із специфічних неадекватних форм людської поведінки. 3 огляду на це слушно було 6 використовувати термін «регіональна злочинність» у сфері інтелектуальної власності. Цей термін відображає територіальні, історичні, соціальні, економічні тощо особливості (відмінності) тих явищ, процесів та їх властивостей, які відображають злочинність взагалі.

У кримінологічній літературі під регіоном розуміється певна частина території країни 3 однорідними соціально-економічними, соціально-психологічними та демографічними ознаками, які зумовлюють особливості злочинності в даномутериторіально-просторовому формуванні. Такий підхід більше підходить до визначення географії злочинності у сфері інтелектуальної власності.

Аналізуючи дані криміногенної ситуації в Україні, можна дійти висновку, що стан злочинності у сфері інтелектуальної власності в регіонах країни є різним і залежить від різних факторів, тому лише повне та всебічне дослідження злочинності в регіонах країни дозволить виявити причини та умови злочинності в країні загалом.
Наприклад, зменшення загальної кількості зареєстрованих злочинів спостерігається в 14 регіонах держави (в Чернівецькій $(-12,4 \%)$, Херсонській (-12,1\%), Дніпропетровській (-10,2\%), Одеській $(-7,1 \%)$ областях та в м. Києві (7,5\%)) [4, с. 74-75].

Збільшилось розкриття злочинів в Україні на 3,1 відсотка. Однак, попри певне зменшення вчинення злочинів та збільшення їх розкриття, дедалі частіше від рук злочинців гинуть водночас двоє i більше осіб, винищуються цілі сім’ї, поширюються вбивства підприємців та працівників комерційних структур. Більшість таких злочинів вчинюється на грунті розподілу сфер впливу між злочинними угрупованнями. Жертвами такого виду злочинності нерідко стають представники засобів масової інформації, органів влади і управління.

Багато організованих злочинних угруповань, що вчиняють злочини у сфері інтелектуальної власності, не лише підтримують зв'язки з угрупованнями інших держав, а й вчиняють злочинні дії за кордоном [5, с. 329].

Принципово важливим є розуміння того, що при вивченні причин регіональної злочинності необхідно враховувати взаємозв'язок кримінологічних характеристик, їхніх конкретних форм, видів та різновидів з соціальним середовищем, в межах якого вони виникають, зумовлюються та існують у сфері інтелектуальної власності. Для забезпечення глибокого і всебічного аналізу мають братися до уваги не лише аномальні, негативні, а й нормальні, нормативні ознаки соціального середовища. Зокрема, враховуються такі характеристики регіону:

- соціально-демографічні (чисельність, густота, статево-віковий та національний склад, міграція населення; співвідношення груп населення за соціально-професійним та сімейним станом; розмір території; дані про типи та види розселення людей (співвідношення міської та сільської місцевостей, чисельність населення у містах, їх функціональні ознаки, темпи розвитку тощо));

- економічні (джерела сировини та інші природні ресурси; промисловий, аграрний або інший економічний профіль; домінуючі галузі господарства; наявність вільних економічних зон; джерела та інтенсивність інвестицій; стан бюджету, співвідношення його прибуткової та витратної частини; рух приватизації та інших економічних реформ; рівень розвитку приватного підприємництва; забезпеченість населення товарами, житлом, послугами; рівень прибутків тощо);

- соціально-культурні (освітній рівень населення; забезпеченість культурними, спортивними закладами; життєвий устрій, звичаї, традиції, стереотипи поведінки, зумовлені етнополітичними, етнопсихологічними, національними, релігійними, історичними та іншими факторами); 
- правоохоронні (сили, задіяні в охороні правопорядку; матеріально-технічна база правоохоронних органів; рівень законослухняності громадян; активність населення в боротьбі з правопорушеннями тощо) [6, с. 44-45; 2, с. 52; 7, с. 151-152].

Це приблизний перелік зовнішньої інформації, яка має враховуватись та використовуватись при кримінологічному аналізі злочинності, її причин та умов.

При вивченні причин та умов регіональної злочинності значну увагу приділяють пов'язаним 3 нею негативним соціальним явищам - пияцтву, наркоманії, токсикоманії, проституції, соціальному паразитизму, виявленню расової, національної ворожнечі, тіньовій економіці, протекціонізму, бюрократизму, безгосподарності. Досліджуючи ці явища, необхідно ширше використовувати різного роду джерела зовнішньої інформації, зокрема й дані економічної, медичної та іншої галузевої статистики, повідомлення засобів масової інформації, матеріали журналістських розслідувань тощо.

При кримінологічному аналізі перелічених негативних явищ регіональної злочинності у сфері інтелектуальної власності досліджуються в динаміці їх стан та рівень (наприклад, відомості про вживання спиртних напоїв в абсолютних цифрах, збільшення його вживання по регіону загалом та на душу населення), структура (наприклад, динаміка пияцтва на виробництві, в побуті, в громадських місцях), своєрідна латентність (наприклад, підпільний алкогольний бізнес) та інші показники, які дозволяють простежити багатогранні зв'язки цих явищ зі злочинністю.

Важливе кримінологічне значення має вивчення характеру правопорушень у сфері інтелектуальної власності для розробки профілактичних заходів, спрямованих проти вказаної злочинності. Ідеться, зокрема, про планування заходів 3 боротьби зі злочинністю на підставі прогнозу розвитку міст. Протягом десятиліть міста проєктувалися і будувалися без урахування того, що злочинність існує як об’єктивна реальність.

Існування відмінностей злочинності можна пояснити. Це безумовна закономірність. Статистичні показники, відображаючи територіальну диференціацію злочинності, не можуть бути завжди рівновеликими. Злочинність у сфері інтелектуальної власності як соціально детерміноване явище залежить від характеру умов соціального життя, які складаються в регіонах, і чутливо реагує на їх зміни та відмінності в цих умовах. Ці умови є різними у різних регіонах.

Аналіз особливостей злочинності в регіональному розрізі передбачає дослідження та вивчення специфіки місцевих економічних, політичних, соціальних та інших умов, які тим чи іншим чином впливають на спосіб життєдіяльності людини, а також тих, що впливають на вчинення різних зло- чинів і на практику боротьби з ними, яка склалася в правоохоронних органах регіонів країни. Цей аналіз служить тією фактологічною базою, спираючись на яку, кримінологи можуть запропонувати як окремим регіонам, так і країні загалом досить грунтовну, гнучку та економічно ефективну комплексну цільову програму дій.

Географія злочинності у сфері інтелектуальної власності - це сукупність злочинних діянь інтелектуального характеру, що мають просторово-часовий розподіл кримінально караних діянь, пов'язаних зі специфікою різних регіонів світу, країн чи адміністративно-територіальних одиниць однієї країни з відповідним освітньо-технічним рівнем, з високим рівнем попиту на незаконне використання інтелектуальної власності.

На думку більшості експертів $(80,5 \%$ ), в Україні реєструється лише один із десяти вчинених злочинів у сфері інтелектуальної власності. Певна частина опитаних $(11,1 \%)$ вважає, що реєструється більше одного з десяти злочинів. Як бачимо, більшість експертів вважає злочини у сфері інтелектуальної власності високолатентними, лише незначна частина - середньолатентними [8, с. 44-45].

Практика показує, що деяка частина злочинів у сфері інтелектуальної власності не розкривається, а часом і зовсім не виявляється, залишається латентною. Складність виявлення таких злочинів та професійної діяльності з надання публічних послуг у сфері інтелектуальної власності полягає в тому, що їх вчинення, крім самих зацікавлених учасників, протягом тривалого часу, а часом і зовсім ніхто виявити не може.

\section{Jimepamypa}

1. Даньшин И.Н. Криминология: понятие, предмет, задачи и система криминологической науки : конспект лекций. Харьков, 1995. 120 с.

2. Джужа О.М., Іванов Ю.Ф. Кримінологія : навч. посіб. Київ : Вид. Паливода А.В. 2008. 292 с.

3. Закалюк А.П. Курс сучасної української кримінології: теорія і практика : у 3 -х кн. Кн. 1 : Tеоретичні засади та історія української кримінологічної науки. Київ : Видавничий дім «Ін Юре». 2007. 424 с.

4. Аналітична довідка про основні тенденції розвитку безпекової ситуації в Україні та стан виконання пріоритетних завдань центральними органами виконавчої влади, діяльність яких спрямовується і координується Міністром, за 2018 рік. Київ : ДНДІ МВС України, 2019. 95 с.

5. Жаровська Г.П. Транснаціональна організована злочинність в Україні: феномен, детермінація, протидія : монографія. Чернівці : Чернівец. нац. ун-т. 2018, 568 c.

6. Кримінологія : підручник / В.В. Голін, Б.М. Головкін, М.Ю. Валуська. Харків : Право. 2014. $440 \mathrm{c}$.

7. Кулик О.Г. Злочинність в Україні на початку XXI століття : монографія. Київ : Юрінком Інтер. 2013. $272 \mathrm{c}$.

8. Про затвердження Положення про порядок ведення Єдиного реєстру досудових розслідувань : Наказ Генеральної прокуратури України від 06 квітня 2016 р. № 139. URL: http://zakon2.rada.gov.ua/laws/show/ z0680-16 (дата звернення: 15.10.2019). 


\section{Анотація}

Tопчій В. В. Географія злочинності у сфері інтелектуальної власності в Україні. - Стаття.

У статті зазначається про необхідність посилення боротьби зі злочинністю у сфері інтелектуальної власності, що вимагає не лише шукати відмінності у кримінологічних ситуаціях регіонів країни, а намагатися встановлювати кримінологічні закономірності, аргументувати їх.

Зазначено, що аналіз географії злочинності є необхідністю для з'ясування специфіки причин та умов злочинності в різних географічних районах з погляду впливу на них місцевих особливостей та врахування їх при розробленні заходів запобігання злочинності у сфері інтелектуальної власності. Географія злочинності має велике практичне значення для диференційованої оцінки результатів роботи правоохоронних органів, їх служб та підрозділів, визначення ними гарячих точок, маневрування силами та засобами, планування всього процесу боротьби зі злочинністю. При вивченні географії злочинності на рівні суб'єктів держави досліджуються її кримінологічні характеристики відносно міст та районів, на рівні міста з районним поділом - відносно районів, на рівні району, міста, селища - відносно населених пунктів, мікрорайонів, адміністративних ділянок, підприємств та інших об’єктів.

Також мають значення і теоретичні дослідження, оскільки з'являється можливість глибше вивчити механізм детермінації злочинності та ii змін, встановити закономірності появи та функціонування злочинності в різних за своїми соціально-економічними, соціально-культурними та іншими характеристиками регіонах, визначати в цих закономірностях загальне та специфічне.

Вказано, що географічна поширеність злочинів проти інтелектуальної власності має свої особливості, зумовлені тим, що ці кримінальні діяння у більшості випадків пов'язані із здійсненням наукової, господарської та підприємницької діяльності. 3 огляду на це особливо поширеними вони є у великих регіонах країни, оскільки саме на цій території сконцентрований інтелектуальний, фінансовий і виробничий потенціал держави. Вказується на можливості підвищення ефективності заходів запобігання на основі диференціації регіонів залежно від індивідуального комплексу факторів, які визначають стан злочинності у сфері інтелектуальної власності й їі конкретні показники.

Ключові слова: інтелектуальна власність, географія злочинності, заходи запобігання, кримінологічна характеристика, механізм детермінації.

\section{Summary}

Topchii $V$. V. Geography of crime in intellectual property in Ukraine. - Article.

The article points to the need to strengthen the fight against crime in the field of intellectual property, which requires not only to look for differences in criminological situations of the regions of the country, but to try to establish criminological laws, to substantiate them.

It is noted that the analysis of crime geography is necessary to find out the specific causes and conditions of crime in different geographical areas in terms of the impact on them of local characteristics and to take them into account when developing measures to prevent crime in the field of intellectual property. It is of great practical importance for the differentiated evaluation of the results of the work of law enforcement agencies, their services and units, their definition of "hot spots", maneuvering of forces and means, planning of the whole process of combating crime. When studying the "geography" of crime at the level of the subjects of the state, its criminological characteristics are investigated in relation to cities and districts; at the city level with district division - relative to districts; at the level of district, city, settlement - relative to settlements, residential districts, administrative districts, enterprises and other objects.

Also relevant are theoretical studies, as there is an opportunity to study more deeply the mechanism of determination of crime and its changes, to establish patterns of occurrence and functioning of crime in different socio-economic, socio-cultural and other characteristics of the regions, to determine in these laws the general and specific.

It is pointed out that the geographical spread of crimes against intellectual property has its peculiarities, due to the fact that these criminal acts, in most cases, are related to the implementation of scientific, economic and business activities. Therefore, they are especially widespread in large regions of the country, since it is in this territory that the intellectual, financial and production potential of the state is concentrated. It points to the possibility of improving the effectiveness of prevention measures based on differentiation of regions, depending on the "individual" set of factors that determine the state of crime in the field of intellectual property and its specific indicators.

Key words: intellectual property, geography of crime, prevention measures, criminological characteristics, mechanism of determination. 